\title{
INTRODUCTION. KOMI FOLKLORE STUDIES: CONNECTING POINTS ${ }^{1}$
}

\section{Liudmila Lobanova}

Researcher

Department of Folklore, Institute of Language, Literature, and History

Komi Science Centre, Russian Academy of Sciences, Russia

Email: sergejluda@mail.ru

\section{Nikolay Kuznetsov}

Lecturer in Finno-Ugric Languages

Department of Finno-Ugric Studies

University of Tartu

Email: nikolai.kuznetsov@ut.ee

The special edition of Folklore: Electronic Journal of Folklore is dedicated to $\mathrm{Komi}^{2}$ folklore and folklore studies. The issue was prepared within the framework of cooperation between the Department of Folkloristics of the Estonian Literary Museum and the Folklore Department of the Komi Science Centre by Komi and Estonian folklore researchers. Prior to this, the authors published one of the issues (vol. 17, 2016) of the Sator periodical, which was also dedicated to Komi folklore studies. The goal of this issue is to present some of the results of recent Komi folklore studies to wider academic circles, overcoming the natural linguistic obstacles. The majority of articles are written within the research project "Local Folklore Traditions of the European Northeast of Russia: Mechanisms of Development and Adaptation, System of Genres, Ethnocultural Folklore Interaction" (№ AAAA-A17-117021310066-4).

The history of Komi folklore studies reveals processes typical for the Russian, Soviet, and post-Soviet research dealing with folklore (the research field extended and became more limited over time), as well as studying the Komi language and culture as part of the general development of Finno-Ugric studies. Traditionally, academician Andreas Sjögren (1794-1855) is considered to have discovered Komi folklore - in 1827, he transcribed folklore texts and published them as examples of the Komi language. Other linguistic researchers have used a similar approach to folklore texts. In 1843, Matthias Alexander 
Castrén transcribed Izhma bridal lamentations and published them under the heading Zyrianskie svadebnye pesni (Zyrian Wedding Songs), which is one of the earliest examples of the Izhma Komi ritual poetry (Filippova 2014). Pavel Savvaitov (1815-1895) included bridal lamentations of Upper-Vychegda in his Grammatika zyrianskago iazyka (Grammar of the Zyrian Language, 1850). Yrjö Wichmann, a Finnish linguist and folklore researcher, gathered folklore materials in 1901-1902 and published them as Komi zyrianskaia narodnaia poeziia (Komi-Zyrian Folk Poetry, 1916). The work is peculiar due to the categorisation of folklore materials by local sub-cultures. Hungarian linguist and folklore researcher David Raphael Fokos-Fuchs (1884-1977) presented the material in a similar way in his Obraztsy narodnoi poezii (Samples of Folk Poetry, 1913), Komi teksty (Komi Texts, 1916), and Fol'klor naroda komi (zyrian) (Folklore of Komi (Zyrian) People, 1951) (Filippova 2007). The scientific research of these authors encouraged local intellectuals to start their own work. As a result, Andrei Tsember published two collections of Komi skazki i pesni (Komi Tales and Songs) in 1913 and 1914.

During Wold War II, Estonian academician Paul Ariste and Finnish linguist Toivo Emil Uotila continued collecting folklore from Komi prisoners of war. Later, Nikolay Kuznetsov (2005, 2006, 2008) and Paula Kokkonen (1985-2006) published their own materials. Unlike the previous publications, the collections are categorised by the origin of people, allowing for precise location and attribution. In terms of genre, the texts are mostly songs, tales, lamentations, riddles, and proverbs.

Linguists have made a huge contribution to developing the principles of collecting and publishing folklore texts, such as rules for noting peculiarities in dialect and reflecting these in publications. This allows preserving authenticity, attributing texts to specific dialects and local folklore traditions, determining the location of sources, and using a bilingual approach (usually, texts are transcribed and translated into German, Russian, Finnish, Estonian, or English). Thanks to the work of linguists, Komi folklore has become well known and the publications of the linguists are still researched.

Early twentieth century brings a completely different approach to researching folklore. Folklore texts are considered a source of knowledge about the past of a nation, its culture, and spirituality, as well as the representation of their ethnic identity. Works by Vasily Nalimov, Pitirim Sorokin, and Kallistrat Zhakov serve as classic examples of this approach. Modern methods required new ways for collecting folklore material, and hence, new programmes were developed (Programme 1924), manuals were created (Startsev 1933), and expeditions were organised (Savin 1926; Lobanova 2017).

Literary, civil, and educational organisations and writers soon opted for a new approach, which resulted in the definition of folklore as traditional oral poetry. 
During that time, collections of folklore materials were published. Introductions to these publications described the peculiarities of Komi folklore, its main types, and poetics: Fol'klornyi sbornik (Folklore Collection, 1938) by Pavel Doronin, Viser vozhsa s'ylankyv"ias da moidkyv"ias (Vishera Songs and Tales, 1941) by Ivan Osipov, and Komi moid"ias, s'ylankyv"ias da poslovitsaias (Komi Tales, Songs, and Proverbs, 1956) by Fedor Plesovsky. Substantial scientific works were written: Svad'ba naroda komi (Komi National Wedding, 1968) by Fedor Plesovsky, Komi epicheskie pesni i ballady (Komi Epic Songs and Ballads, 1969) by Anatoly Mikushev, Detskie pesni i skazki (Songs and Tales for Children, 1969) by Yuri Rochev, and others. During this period, a vast amount of folklore materials was gathered in all regions of the Komi Republic and beyond, previously unknown forms and genres (epic) were found, the then state of Komi folklore was researched, works belonging to the main genres were published, and summarising reviews were written.

The trend gained a new momentum with the publishing of the corpus of the folklore of the nations of the USSR, following the examples of the corpus of Russian folklore (Gorelov 1977). The first step was to publish the three-volume song collection Komi narodnye pesni (Komi Folk Songs, 1966, 1968, 1971) by a group of authors (Anatoly Mikushev, Prometey Chistaliov, Yuri Rochev), and Anatoly Mikushev's monograph Epicheskie formy komi fol'klora (Epic Forms of Komi folklore, 1973). Then, the academic corpus of the verbal cultural heritage of the indigenous population of the Komi Republic was extended and the following collections were compiled and published: Komi poslovitsy i pogovorki (Komi Sayings and Proverbs, 1973), Komi narodnye zagadki (Popular Komi Riddles, 1975), and Komi skazki (Komi Tales, 1976) by Fedor Plesovsky; Komi legendy i predaniia (Komi Legends and Lore, 1984), Komi skazki (Komi Tales, 1991), and Komi starinnye detskie igry (Traditional Komi Children's Games, 1988) by Yuri Rochev, Prometey Chistaliov's monograph titled Komi narodnye muzykal'nye instrumenty (Komi Folk Music Instruments, 1984), and the collection Komi narodnye primety (Komi Folk Portents, 1993) by Vera Kudriashova. The first summarising analysis of Komi folklore, Istoriia komi literatury: Fol'klor (History of Komi Literature: Folklore), was published in 1979. The most significant achievement of Komi folklore studies in this period was Komi narodnyi epos (Komi Folk Epic, 1987) by Anatoly Mikushev, which was published within the series Epos narodov SSSR (Epics of the Peoples of the USSR, 1971-1990).

In preparing the publications, the researches enjoyed vast public attention and support. Field researches of Komi folklore culture were carried out in the territory of the republic and in the areas of concentrated Komi population (Siberia, Murmansk Oblast, Nenets Autonomous Okrug). The fieldwork material required archiving and systematisation to enable research, description, and preparation for issuing publications, and hence, the publishing of folklore 
collections began. There are three archives comprising the main part of the expedition materials collected since 1939. The folklore collections of the Scientific Archive of the Komi Science Centre consist of typewritten and handwritten reports summarising the results of the expeditions starting from 1939.

Since 1957, folklorists have been regularly using tape recorders for their field studies, but as the researchers in all institutes of the Komi subsidiary of the Russian Academy of Sciences focused on forming a united scientific archive (handwritten documents), the collectors held the audio materials in their possession and a recordings library was established only in the late 1970s. In 2000, the recordings library was transformed into the Folklore Archive of the Institute of Language, Literature, and History, and today it is the largest library of traditional Komi culture-related audio and video recordings. The staff maintain, describe, systematise, and restore records of folklore and ethnographic materials. Similar materials are stored in the Folklore Archive of the Syktyvkar State University, where most of the collections were started in the second half of the 1980s. The peculiarity of this archive lies in the geography of the expeditions, as in addition to Komi traditions, the researchers paid special attention to the exploration of the Russian and mixed Komi-Russian areas of the Komi Republic, as well as of the neighbouring territories - Arkhangelsk and Kirov oblasts (Savelyeva 2012).

In the 1990s, Komi folklore studies were freed from the ideological dictate of the Soviet literature studies, which traditionally (and often artificially) had been tied to folklore in Russia since the 1930s. Folklore researchers got the opportunity to explain and interpret folklore facts through ethnography, which inevitably brought folklore studies to the realm of traditional religious beliefs, as studies of the latter belong to ethnography.

On the other hand, in the same period, ethnography was allowed to explore religious and mythological forms of folk life and ethnographers started including folklore facts in their studies. Therefore, the Institute of Language, Literature, and History supported the cooperation in ethnography and folklore studies under the general theme of 'Spiritual Culture of the Peoples in the NorthEast of the European Part of Russia'. Within the framework of the theme, the institute published several collections of scientific articles (including those by folklorists), Pavel Limerov's monograph Mifologiia zagrobnogo mira (Mythology of the Netherworld, 1999) and Oleg Uliashev's monograph Tsvet $v$ predstavleniiakh $i$ fol'klore komi (Colour in the Komi Beliefs and Folklore, 1999), as well as Mifologiia komi (Komi Mythology Encyclopaedia, 1999), which became the first volume of the Encyclopaedia of Urals Mythologies and was translated into English and Estonian.

In 2001, a folklore department was created at the institute. Today, folklorists continue their scientific description, systematisation, and publication of folklore 
materials in fields such as prose fairy tales, ritual folklore, poetry for charms and spells, non-fairy-tale prose, children's folklore, paremiology, and traditional Russian folklore in the Komi Republic. Theoretical and analytical studies explore the genre and poetical peculiarities of folklore texts, the dynamics of folklore genres, and the development of forms in the twentieth and early twenty-first centuries, the local peculiarities of folklore facts, folklore adaptation, mechanisms for the adaptation of folklore texts, and absorption by foreign environments, and the influence of the situation on presenting folklore texts (Krasheninnikova 2016). Information about publications and studies is included in the Bibliographic Index on the website of the Institute of Language, Literature, and History (see Bibliography 2015).

Recently, folklore expeditions have become regular and a comprehensive approach to selecting, collecting, and registering materials has proven useful. The emphasis on collecting the materials that earlier escaped the attention of folklorists allowed filling in the gaps in a number of research fields. The collected materials cover several important topics of modern folklore traditions and genres: calendar rituals, family rituals, religious, children's, and motherhood folklore, folk demonology, poetry for charms and spells, folklore (fairy-tale and non-fairy-tale) prose, etc. Researchers explain the lyrics of ritual and non-ritual poetry, songs, games, and other vocal and musical genres.

The geography of the field research is not limited to the Komi Republic; we also explore Russian and Komi local traditions, areas neighbouring the republic, and other territories of Komi residence (Nenets Autonomous Okrug of the Arkhangelsk Oblast, Yamalo-Nenets Autonomous Okrug, and Khanty-Mansi Autonomous Okrug of the Tyumen Oblast, Komi-Permyak Okrug of Perm Krai, Arkhangelsk and Kirov oblasts) (Krasheninnikova 2015).

This publication is an excerpt of today's Komi folklore studies. The articles present various methodological approaches to the selection and analysis of folklore material as well as the scientific interests of Komi folklore researches. The authors of the articles are leading Komi folklorists, researchers of the folklore and ethnography departments of the Institute of Language, Literature, and History at the Komi Science Centre of the Urals Subsidiary of the Russian Academy of Sciences.

The collection opens with an article by Oleg Uliashev about the ethnic-cultural and ethnic-genetic links between the Komi, Khanty, and Mansi peoples. On the basis of folklore and ethnographic and historical materials, the author suggests that some Khanty groups are formed of Komi, Khanty, and Mansi components.

Pavel Limerov analyses some storylines of Komi legends about the creation of the world. The object of analysis is a contamination of mythological stories of earth-diving and world creation from an egg. The article considers in detail the main components of the stories that have no parallel in similar texts, and offers a hypothesis about the origins of these components. 
Anatoly Panyukov studies the origin and usage of zaum' - a complicated and very peculiar phenomenon. The author analyses one particular example of the Komi charming ritual and offers a hypothesis that linguistic transformations known as zaum' can appear as a result of using the source text in the rhythmic matrix of becharming procedures.

The article by Liudmila Lobanova is dedicated to the verbal component of cattle-breeding rituals. The becharming texts are divided into five types: sentence, ritual dialogue, spell, lamentation, and prayer. A structural and semantic analysis of the most popular sentences gives rise to the definition of two types of texts: close-structure and open-structure sentences.

The article by Aleksey Rassykhaev, an explorer of the Komi play-folklore, is dedicated to a children's game of calling a house spirit (domovoi), which is unique for the traditional Komi culture. Various versions of the game have similar scenarios and the goal of the game is to verify whether the creature exists, and establish contact with it. The author analyses the descriptions of the game and introduces into scientific use new authentic texts and archived materials not used earlier.

Two more articles deal with the Christmas rituals of various local traditions. Galina Savelyeva presents the dynamics of Christmas youth gatherings in the Vishera micro-local tradition. The author describes the different stages of this set of rituals: traditional, Soviet-time teenagers, and today.

The article by Yulia Krasheninnikova and Svetlana Nizovtseva introduces folklore materials collected in the twenty-first century from the Russian population of the mining settlements in the Komi Republic, founded when iron mining started in the area in the middle of the eighteenth century. The folklore traditions originated from the Russian settlers coming from the northern, northeastern, and central provinces of the European part of the Russian Empire. The authors analyse the Christmas rituals and the poetry used by children and adults when visiting neighbours during Christmas.

The final article of the collection by Yulia Krasheninnikova, Head of the Folklore Department of the Institute of Language, Literature, and History, analyses the scenarios of oral historical prose in the same local traditions.

We hope that the goal of this issue of the journal will be achieved and the readers will have a certain understanding of the history and current state of Komi folklore studies, that the articles by the Komi folklorists in the Folklore: Electronic Journal of Folklore will contribute to overcoming the language barrier, and that Komi folklore will be better represented in the world folklore science. We express our gratitude to the authors and reviewers of the articles, to the editorial staff of the journal for the work they did, to the Kindred Peoples' Programme of the Ministry of Education and Research of the Republic of Estonia, and to the Centre of Excellence in Estonian Studies for the financial support. 


\section{NOTES}

1 The overview on this topic is based on the following articles: Mikushev \& Rochev \& Chistaliov 1979; Limerov 2006; Krasheninnikova 2015, 2016.

2 The Komi language belongs to the Permic group of the Finno-Ugric languages together with its close relative Udmurt. It is divided into two main dialect groups: Komi-Zyrian and Komi-Permyak. The name Komi is usually applied to the Komi-Zyrian variety of the language, and to the Komi-Zyrian people. The majority of the Komi people live in the Komi Republic (capital Syktyvkar). The republic is a federal subject of Russia, and it is located in the north-eastern corner of Europe, to the west of the Urals. There are also compact Komi settlements outside the republic: on the Kola Peninsula and in western Siberia. The Komi-Permyaks live south from the Komi Republic, in the former Komi-Permyak Autonomous District (capital Kudymkar) in the Perm Territory. According to the latest census in 2010, there were 228,235 Komi-Zyrians in Russia, and the number of Komi-Permyaks was 94,456.

\section{REFERENCES}

Bibliography 2015 = Bibliograficheskii ukazatel' sektora fol'klora IIaLI Komi NTs UrO RAN (1970-2014 gg.) [Bibliographic Index of the Folklore Department of the ILLH at the Komi Science Centre of the Urals Subsidiary of the RAS (1970-2014).] Syktyvkar: Komi NTs UrO RAN. Available at https://illhkomisc.ru/wp-content/ uploads/2018/10/ukazatel_folkloristy_2007-2014-gg._posl.-var..pdf, last accessed on 10 April 2019.

Filippova, Valentina 2007. Traditsionnaia kul'tura komi v finskikh i vengerskikh izdaniiakh. [Traditional Komi Culture in Finnish and Hungarian Publications.] In: T. Ivanova (ed.) Riabininskie chteniia-2007: Materialy Vnauchnoi konferentsii po izucheniiu narodnoi kul'tury Russkogo Severa. [Ryabinin Readings - 2007: Proceedings of the 5th Scientific Conference for Studying the Popular Culture of the Russian North.] Petrozavodsk: Muzei-zapovednik “Kizhi”, pp. 124-125. Available at http://kizhi.karelia.ru/library/ryabinin-2007, last accessed on 23 April 2019.

Filippova, Valentina 2014. Obriadovaia poeziia komi v zapisiakh XIX veka. [Komi Ritual Poetry Recorded in the 19th Century.] In: V. Filippova. Traditsionnaia kul'tura i fol'klor komi: sbornik trudov. [Traditional Culture and Komi Folklore: Collection of Works.] Syktyvkar: Izdatel'skii dom Komi, pp. 41-46.

Gorelov, Aleksandr 1977. Svod russkogo fol'klora: Prospekt. [Corpus of Russian Folklore: Prospectus.] In: A. Gorelov (chief ed.) Russkii fol'klor: Problemy "Svoda russkogo fol'klora". [Russian Folklore. Problems of the Corpus of Russian Folklore.] Vol. 17. Leningrad: Nauka, pp. 4-10. Available at http://lib2.pushkinskijdom.ru/ Media/Default/PDF/RusFolk/RusFolklore\%20vol.17\%201977.pdf, last accessed on 23 April 2019.

Krasheninnikova, Yulia 2015. Vstupitel'noe slovo k izdaniiu. [Introduction to the Issue.] In: Bibliograficheskii ukazatel' sektora fol'klora IIaLI Komi NTs UrO RAN (19702014 gg.) [Bibliographic Index of the Folklore Department of the ILLH at the Komi SC of the Urals Subsidiary of the RAS (1970-2014).] Syktyvkar: Komi NTs UrO RAN, pp. 2-3. Available at https://illhkomisc.ru/wp-content/uploads/2018/10/ ukazatel_folkloristy_2007-2014-gg._posl.-var..pdf, last accessed on 10 April 2019. 
Krasheninnikova, Yulia 2016. Ot redaktora. [From the Editor.] In: Y. Krasheninnikova (chief ed.) Fol'kloristika Komi. Fol'klornye zhanry Evropeiskogo Severo-Vostoka Rossii: dinamika razvitiia, transformatsii, klassicheskoe nasledie i sovremennye formy. [Komi Folklore. Folklore Genres of the European North-East of Russia: Development Dynamics, Transformation, Classic Heritage, and Modern Forms.] Syktyvkar: Komi NTs UrO RAN, pp. 3-4. Available at https://docplayer. ru/56498129-Folkloristika-komi-folklornye-zhanry-evropeyskogo-severo-vostokarossii-dinamika-razvitiya-transformacii-klassicheskoe-nasledie-i-sovremennyeformy.html, last accessed on 23 April 2019.

Limerov, Pavel 2006. Komi fol'kloristika: Itogi i perspektivy. [Komi Folklore Studies: Results and Perspectives.] In: L. S. Lobanova \& A. N. Rassykhaev (comps.) Bibliograficheskii ukazatel' rabot Instituta iazyka, literatury i istorii Komi Nauchnogo Tsentra UrO RAN (1970-2005). Vypusk 3: Trudy uchonykh otdela fol'klora. [Bibliographic Index of the Institute of Language, Literature, and History at the Komi Science Centre of the Urals Subsidiary of the RAS (1970-2005). Vol. 3: Proceedings of Researchers of the Folklore Department. (Compiled by L. S. Lobanova and A. N. Rassykhaev).] Syktyvkar, pp. 3-8. Available at https:// illhkomisc.ru/wp-content/uploads/2014/11/folk.pdf, last accessed on 23 April 2019.

Lobanova, Liudmila 2017. Proizvedenie V. A. Savina "'Musiur' saiyn” kak istochnik po fol'klornoi traditsii visherskikh komi pervoi treti XX v. ["Musiur saiyn" by V. A. Savin as a Source of Folklore Tradition of Vishera Komi of the First Third of the 20th Century.] In: J. Krasheninnikova (chief ed.) Filologicheskie issledovaniia-2017. Fol'klor, literatura i iazyki narodov evropeiskoi chasti Rossii: formy, modeli, mekhanizmy vzaimodeistviia. [Philological Studies-2017. Folklore, Literature, and Languages of Peoples of the European Part of Russia: Forms, Models, Mechanisms of Interaction.] Syktyvkar: Komi NTs UrO RAN, pp. 51-56.

Mikushev, Anatoly \& Rochev, Juri \& Chistaliov, Prometey 1979. Istoriia sobiraniia i izucheniia komi fol'klora. [The History of Collecting and Studying Komi Folklore.] In: A. Mikushev (chief ed.) Istoriia komi literatury: Fol'klor. [History of Komi Literature: Folklore.] Vol. 1. Syktyvkar: Komi kn. izd-vo, pp. 11-24.

Programme 1924 = Programmy po izucheniiu Komi kraia (Obshchestvo izucheniia Komi kraia). [Programmes for the Exploration of the Komi Region (Society for Exploring the Komi Region).] Ustsysolsk: Komi izd-vo. Available at https://www.prlib. ru/item/361071, last accessed on 23 April 2019.

Savelyeva, Galina 2012. Fol'klornaia traditsiia komi v arkhivnykh fondakh respubliki. [Komi Folklore Tradition in the Archival Records of the Republic.] In: Aktual'nye problemy narodnogo khudozhestvennogo tvorchestva $v$ sovremennoi kul'ture: Materialy mezhregional'noi nauchno-prakticheskoi konferentsii. [Topical Problems of Popular Art in Modern Culture: Proceedings of the Inter-regional Scientific and Practical Conference.] Syktyvkar: GAU RK Tsentr narodnogo tvorchestva i povysheniia kvalifikatsii, pp. 23-32.

Savin, Viktor 1926. "Musiur" saiyn. Viser vozhöd komi iözkostsa s’ylankyv"ias chukörtöm. [Beyond the Watershed: Collection of Komi Popular Songs in Vishera.] Komi mu Zyrianskii krai [Komi Mu - Zyrian Krai] No. 9, pp. 33-41; No. 10, pp. 35-38; No. 11, pp. 35-43.

Startsev, Georgy 1933. Komi fol'klor (ego izuchenie i znachenie, zhanry, detskii fol'klor, kak $i$ chto izuchat'). [Komi Folklore (Its Studies and Significance, Genres, Children's Folklore, What and How to Study).] Syktyvkar: Komi Gosizdat. 